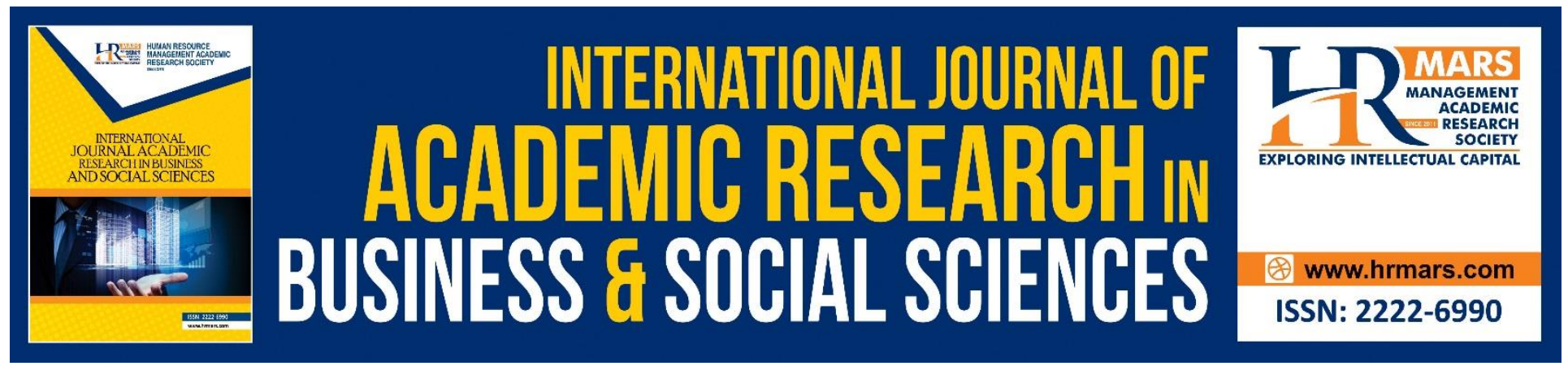

\title{
Enhancing ESL Learners' Writing Skills via ProvWrit
}

\author{
Fatin Khairani Khairul Azam, Fadziana Fadhil, Melor Md. Yunus
}

To Link this Article: http://dx.doi.org/10.6007/IJARBSS/v9-i1/5467

DOI: $\quad 10.6007 /$ IJARBSS/v9-i1/5467

Received: 07 Jan 2019, Revised: 01 Feb 2019, Accepted: 05 Jan 2019

Published Online: 07 Feb 2019

In-Text Citation: (Azam, Fadhil, \& Yunus, 2019)

To Cite this Article: Azam, F. K. K., Fadhil, F., \& Yunus, M. M. (2019). Enhancing ESL Learners' Writing Skills via ProvWrit. International Journal of Academic Research in Business and Social Sciences, 9(1), 660-669.

\section{Copyright: (c) 2019 The Author(s)}

Published by Human Resource Management Academic Research Society (www.hrmars.com)

This article is published under the Creative Commons Attribution (CC BY 4.0) license. Anyone may reproduce, distribute, translate and create derivative works of this article (for both commercial and non-commercial purposes), subject to full attribution to the original publication and authors. The full terms of this license may be seen at: http://creativecommons.org/licences/by/4.0/legalcode

Vol. 9, No. 1, 2019, Pg. 660 - 669

http://hrmars.com/index.php/pages/detail/IJARBSS

JOURNAL HOMEPAGE

Full Terms \& Conditions of access and use can be found at http://hrmars.com/index.php/pages/detail/publication-ethics 


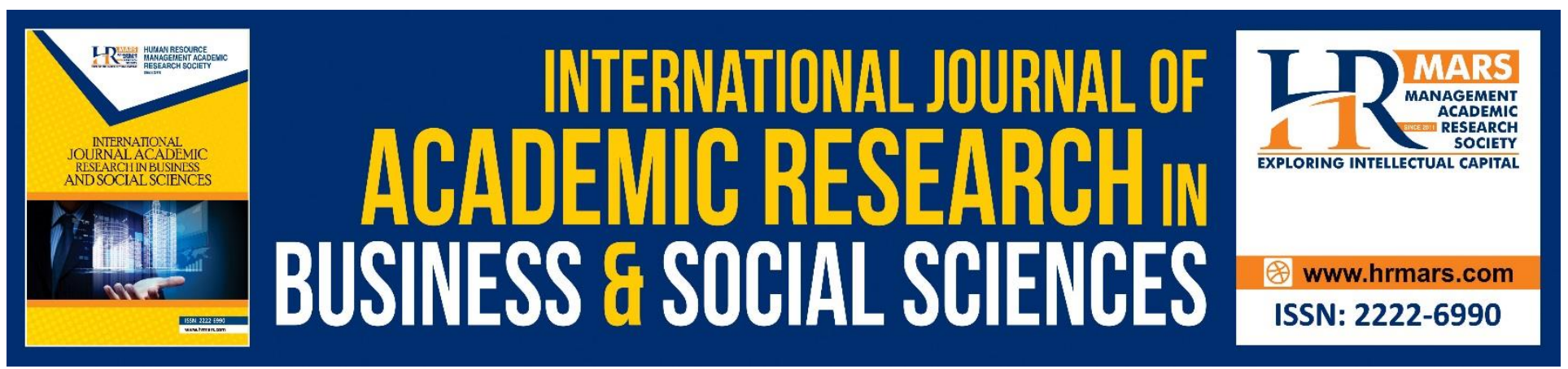

\title{
Enhancing ESL Learners' Writing Skills via ProvWrit
}

\author{
Fatin Khairani Khairul 'Azam', Fadziana Fadhil'2, Melor Md. Yunus ${ }^{3}$ \\ SMK Taman Desa Jaya, Pasir Gudang, Johor, Malaysia ${ }^{1}$ \\ SMK Dato' Abu Bakar Baginda, Sepang, Selangor, Malaysia ${ }^{2}$ \\ Faculty of Education, Universiti Kebangsaan Malaysia, Bangi, Selangor ${ }^{3}$ \\ Email: fatinkhairani@gmail.com ${ }^{1}$,fadziana@smkdabb.edu.my², \\ melor@ukm.edu.my ${ }^{3}$
}

\begin{abstract}
Good writing skills are important to allow to communicate the message with clarity. Incorporating proverbs into teaching writing would enhance learners' writing skills as it promotes their creativity and critical thinking. Furthermore, by integrating ICT in teaching writing, it can make the process easier and fun. The action research of quasi-experimental design was used to investigate the effectiveness of using proverbs via a game-based learning platform; Kahoot and an online forum learning platform; PinUp in improving pupils' writing skills. The participants of the study comprised 29 form 1 pupils from a secondary school in Pasir Gudang, Johor, Malaysia and 27 form 3 pupils from a secondary school in Sepang, Selangor, Malaysia. All participants were required to sit for pre- and post-tests to track their writing performance. The findings revealed that ProvWrit is an effective tool in teaching writing skills as the performance of pupils in writing was improved during the post tests and increased their motivation to learn. It is hoped that the findings of the study would be useful to the teachers incorporating proverbs in teaching to enhance pupils' writing skills. It is suggested that future study should focus on the perceptions of the teachers as well.
\end{abstract}

Keywords: Proverbs, Kahoot, Pinup, Esl Learners, Writing Skills

\section{INTRODUCTION}

The purpose of teaching writing skills in the schools is to prepare the pupils for their higher learning education and to be able to face the real world outside their classrooms. As cited in Yunus \& Chan (2016), writing has been widely regarded as a crucially essential skill in the teaching and learning of English as a Second Language (ESL) as it is a comprehensive skill that helps reinforce vocabulary, grammar, thinking and planning. Pupils in secondary school will need to learn how to write well organized and carefully reasoned essays. Therefore, it is essential to give pupils enough time in prewriting activities to gather their thoughts, discover the language needed to express them and establish the focus of the composition.

Parallel to the $21^{\text {st }}$ century outlook, the researchers integrated the use of ICT in writing classes to make teaching and learning interactive and fun for the millennial pupils. The researchers used 
quizzes via a game-based learning platform; Kahoot and PinUp forum in the pre-writing stage to assess and monitor pupils' learning progress. In a study conducted by Madut and Yunus (2016), they argued that using innovative material is an alternative and unconventional way of teaching which helps pupils to acquire an effective language competence in the target language.

Besides, incorporating proverbs into teaching writing will effectively help pupils to develop their critical and creative thinking skills. Sudiran (2007) as cited in Baharian and Rezai (2017) investigated the role of proverbs in the development of writing skills. As proverbs contain moral values, they can be used as teaching aids because they can motivate ESL learners in order to learn writing seriously. In researchers' experiences of teaching writing lessons and examining secondary school pupils' writing scripts, we found out that most of the pupils frequently misused proverbs in writing, misunderstood the meanings and lack of confidence to use proverbs in their writing. Hence, this research specifically aims to investigate the effect of ProvWrit in enhancing ESL learners' writing skills.

\section{LITERATURE REVIEW}

\section{The Difficulties in Teaching Writing Conventionally}

The studies carried out by the Malaysian Examinations Council (2016) highlighted that the majority of the pupils find it difficult to express themselves in the language. According to Firmansyah (2015), the major problems faced by pupils in writing are their inadequacy of the ability to generate ideas. The struggles become more difficult and problematic as academic tasks become more challenging. A study by Che Mat \& Yunus (2014) claimed that the best way for the teachers is to create a comfortable environment for students to learn the language at their own pace.

\section{ICT in Teaching Writing Skills}

The usage of ICT is helping in the teaching and learning process. According to Yunus et. al (2009), the rapid growth and improvement in ICT have to lead to the diffusion of technology in education. From the results of the case study conducted by Ab. Wahab et.al (2018) focused on the implementation of features in a blended learning approach, it can be concluded that integrating multimedia in writing lessons has enhanced the marks of the students. Results obtained from their marks show that the marks have been better since this new methodology have been implemented. The students started to view writing as easy, exciting and interesting after they had completed their online activities.

\section{Incorporating Proverbs in Writing (ProvWrit)}

According to Mieder (2004), a proverb is a short, generally known sentence of the folk which contains wisdom, truth, morals, and traditional views in a metaphorical, fixed and memorizable form. Dwi Haryanti (2017) stated that proverbs provide an opportunity to improve thinking and writing as pupils both provide and receive information. The result also shows that ESL learners established enhancement in composing better essays in terms of development, organization and thinking with the use of proverbs in writing. The finding is generally dependable with previous studies (Kim et. al., 2017; Maurya et. al, 2018) that indicated a positive effect of using proverbs on promoting ESL learners' critical thinking. On account of that, the researchers believe the use of ProvWrit in enhancing writing skills has positive effects in enhancing ESL learners' writing performance. 


\section{RESEARCH METHODOLOGY \\ Research Design}

The action research of quasi-experimental design was conducted for seven weeks to collect the data which the cycle was adapted from the action research series of cycle, reflection, planning and action, Kemmis and McTaggart (1988). The study did not use the control group for comparison. 29 form 1 pupils of suburban secondary school in Pasir Gudang, Johor; the southern part of Peninsular Malaysia and 27 form 3 pupils of the suburban secondary school in Sepang, Selangor; the west coast of peninsular Malaysia were selected. The main data was collected based on the writing marks recorded in pre- and post-test writing.

Participants were required to answer quizzes in Kahoot by selecting the correct proverbs of the given meanings. Before the actual writing activity, participants were briefly explained the meaning of the proverbs to help them moved their thoughts. Participants wrote sentences and later short paragraphs on a chosen proverb and submitted them in the forum discussion (PinUp). Then, each participant read their stories and share their feedback. All participants were required to sit for pre- and post-tests to track their writing performance. The results of the tests had been tabulated and the mean scores are used to compare the results pre- and post-tests in each suburban secondary school. A paired two sample t-test was conducted to identify the difference between means for both tests.

\section{RESEARCH FINDINGS}

This research was carried out in two suburban schools in Johor and Selangor in August 2018. The action research of quasi-experimental design was used to collect the data exploring the effectiveness of ProvWrit in enhancing ESL learners' writing skills. Before the treatment session began, the participants wrote pre-test essays to determine their level of proficiency. The question is using a PT3 exam format; question 3(i) short writing task. They are given scores to each composition using PT3 short writing marking criteria.

The participants were required to participate and be involved in the tasks prepared including online quizzes in Kahoot and forum discussion, PinUp in the next phase. All participants considered themselves to be competent users of online technology, including browsing the internet and using email and text chat. In the final phase, they were each required to write a post-test essay after seven weeks of participation to figure out the effectiveness of ProvWrit. The results of the tests were analysed and presented in the form of means. The means of the tests were compared. 
INTERNATIONAL JOURNAL OF ACADEMIC RESEARCH IN BUSINESS AND SOCIAL SCIENCES

Vol. 9, No. 1, Jan, 2019, E-ISSN: $2222-6990$ @ 2019 HRMARS

Result for Suburban School, Pasir Gudang, Johor :

Figure 1. Comparison of mean between Pre Test and Post Test

\section{Comparison of mean between Pre Test and Post Test}

6

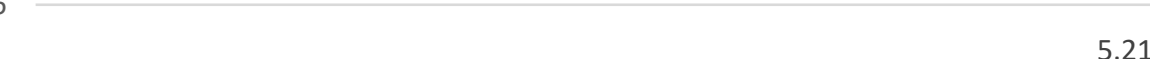

5

3.86

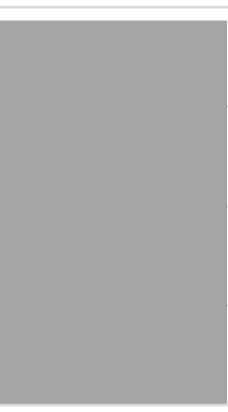

Pre Test

5.21

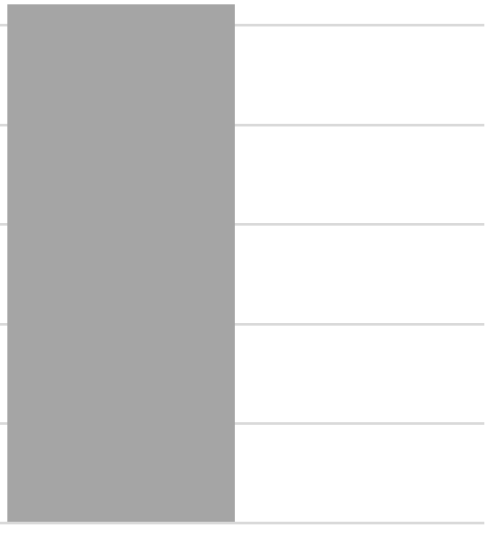

Post Test

Figure 1

Figure 1 shows the mean for both pre-test and post-test. For pre-test, pupils obtained total marks of 112 with mean score of 3.86 For post-test, pupils obtained 151 marks with mean score of 5.21. The rise of 1.35 mean score indicates that ProvWrit did help to enhance pupils at suburban secondary school in Pasir Gudang, Johor; the southern part of Peninsular Malaysia writing skills.

Table 1. Tests of Normality

\begin{tabular}{llll}
\hline \multicolumn{3}{c}{ Shapiro-Wilk } \\
\hline & Statistic & df & Sig. \\
\hline PreTest & .914 & 29 & .022 \\
PostTest & .930 & 29 & .055 \\
\hline
\end{tabular}

Shapiro-Wilk test can be used to test the normality of a distribution when the sample size, $\mathrm{n}<50$ as suggested by Riffenburgh (2012). Since there were only 29 samples in this suburban school, ShapiroWilk test has been conducted and the data collected are normal with sig. $=0.022$ for pre-test and sig. $=0.055$ for post-test, $p>0.05$.

Table 2. Paired Sample T-Test

\begin{tabular}{ccccccc}
\hline \multicolumn{7}{c}{ Paired Differences } \\
\hline & Mean & $\begin{array}{c}\text { Std. } \\
\text { Deviation }\end{array}$ & $\begin{array}{c}\text { Std. Error } \\
\text { Mean }\end{array}$ & t & df & $\begin{array}{c}\text { Sig. (2- } \\
\text { tailed) }\end{array}$ \\
\hline $\begin{array}{l}\text { PreTest- } \\
\text { PostTest }\end{array}$ & -1.34483 & 1.14255 & .21217 & -6.339 & 28 & .000 \\
\hline
\end{tabular}


Paired two sample t-test has also been done to compare the difference between means for pre-test and post-test. The relevant results for the paired t-test are in bold. From this row observe the t statistic, $t=-6.339$, and $p=0.000$; i.e, a very small probability of this result occurring by chance, under the null hypothesis of no difference. The null hypothesis is rejected, since $p<0.05$ (in fact $p=0.000)$.

There is strong evidence $(t=6.339, p=0.000)$ that the teaching intervention improves writing marks. In this data set, it improved marks, on average, by approximately -1 points. If other samples of marks were collected, a possible 'mean paired difference' in marks different is from -1.34 . The $95 \%$ Confidence Interval $(95 \% \mathrm{Cl})$ is important in the study. If the experiment is conducted 100 times, 95 times the true value for the difference would lie in the $95 \%$ confidence interval. In this study, the $95 \%$ $\mathrm{Cl}$ is from -1.8 to -0.9 .

This confirms that the difference in marks is statistically significant. Thus, the study shown significant difference between means for pre-test and post-test with $t(28)=-6.339, p<0.05[95 \% \mathrm{Cl}=$ -1.8 to -0.9 ]. ProvWrit proved to prepare pupils for tactical and strategic learning, enhance their writing skills and achieve better scores in writing tasks of participants in this suburban school.

\section{Result for Suburban School, Sepang, Selangor:}

Figure 2. Comparison of mean between Pre Test and Post Test

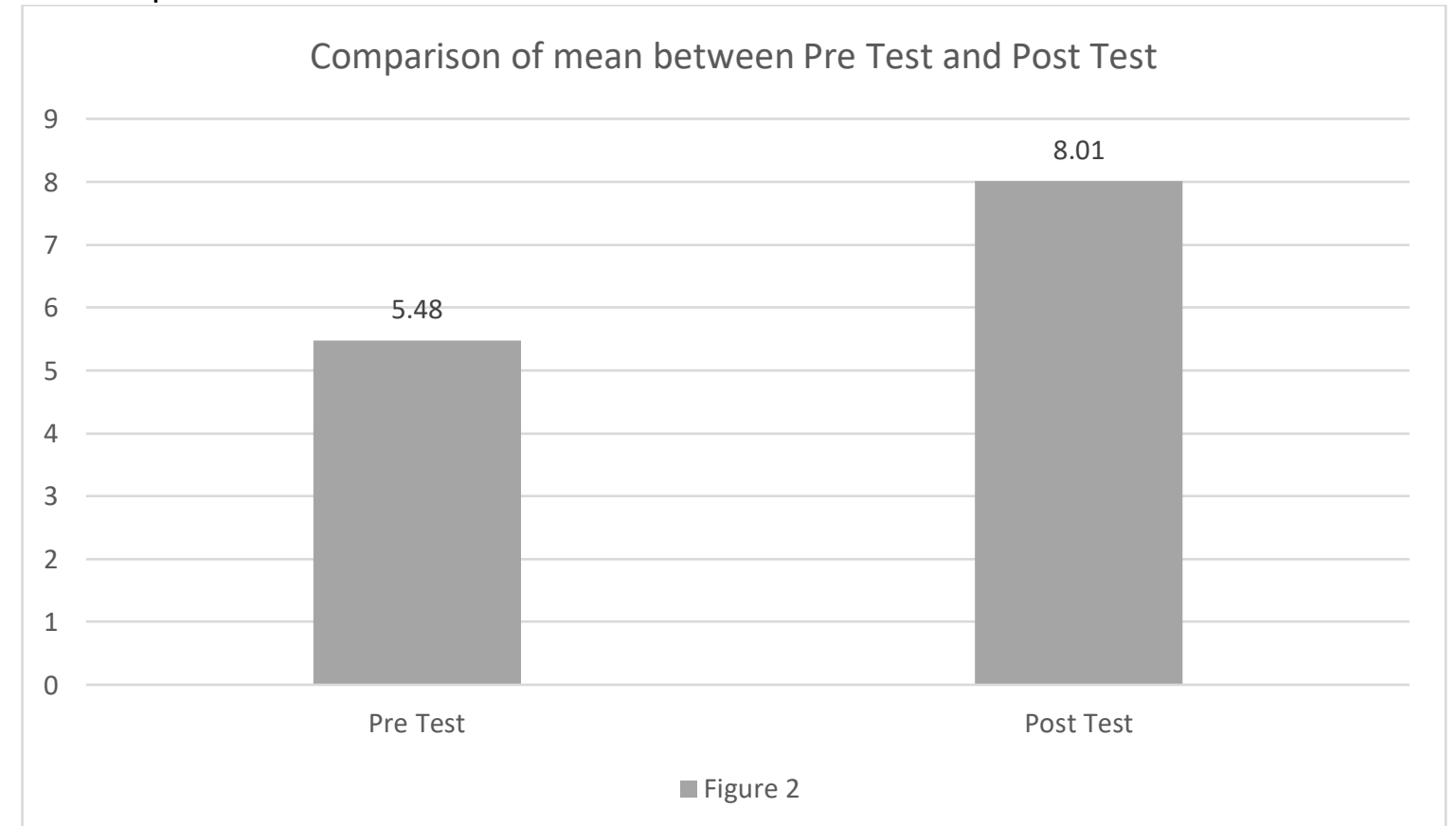

Figure 2 shows the mean for both pre-test and post-test. For pre-test, pupils obtained total marks of 148 with mean score of 5.48 For post-test, pupils obtained 223 marks with mean score of 8.01 . The rise of 2.53 mean score indicates that ProvWrit did help to enhance pupils at suburban secondary school in Sepang, Selangor; the west coast of peninsular Malaysia writing skills. 
INTERNATIONAL JOURNAL OF ACADEMIC RESEARCH IN BUSINESS AND SOCIAL SCIENCES Vol. 9, No. 1, Jan, 2019, E-ISSN: 2222-6990 @ 2019 HRMARS

Table 3. Tests of Normality

\begin{tabular}{llcl}
\hline & \multicolumn{3}{c}{ Shapiro-Wilk } \\
& Statistic & df & Sig. \\
\hline PreTest & .942 & 27 & .140 \\
PostTest & .827 & 27 & .000 \\
\hline
\end{tabular}

As suggested by Riffenburgh (2012), Shapiro-Wilk test can be used to test the normality of a distribution when the sample size, $\mathrm{n}<50$. Since there were only 27 samples in this suburban school, Shapiro-Wilk test has been conducted and the data collected are not normal with sig. $=0.140$ for pretest and sig. $=0.000$ for post-test, $p<0.05$. Thus, paired sample t-test is applied later to determine the significant difference between means for pre-test and post-test.

Table 4. Paired Sample T-Test

\begin{tabular}{ccccccc}
\hline \multicolumn{7}{c}{ Paired Differences } \\
\hline & Mean & $\begin{array}{c}\text { Std. } \\
\text { Deviation }\end{array}$ & $\begin{array}{c}\text { Std. Error } \\
\text { Mean }\end{array}$ & t & df & $\begin{array}{c}\text { Sig. (2- } \\
\text { tailed) }\end{array}$ \\
\hline $\begin{array}{l}\text { PreTest- } \\
\text { PostTest }\end{array}$ & -2.51852 & 1.15593 & .22246 & -11.321 & 26 & .000 \\
\hline
\end{tabular}

Paired two sample t-test has also been done to compare the difference between means for pre-test and post-test. The relevant results for the paired t-test are in bold. From this row observe the $t$ statistic, $t=-11.231$, and $p=0.000$; i.e, a very small probability of this result occurring by chance, under the null hypothesis of no difference. The null hypothesis is rejected, since $p<0.05$ (in fact $\mathrm{p}=0.000$ ).

There is strong evidence $(t=-11.321, p=0.000)$ that the teaching intervention improves writing marks. In this data set, it improved marks, on average, by approximately -2 points. If other samples of marks were collected, a possible 'mean paired difference' in marks different is from -2.52 . The $95 \%$ Confidence Interval $(95 \% \mathrm{Cl})$ is important in the study. If the experiment is conducted 100 times, 95 times the true value for the difference would lie in the $95 \%$ confidence interval. In this study, the $95 \%$ $\mathrm{Cl}$ is from -3.0 to -2.1 .

This confirms that the difference in marks is statistically significant. Thus, the study shown significant difference between means for pre-test and post-test with $t(26)=-11.321, p<0.05$ [ $95 \% \mathrm{Cl}=$ -3.0 to -2.1 ] . ProvWrit proved to prepare pupils for tactical and strategic learning, enhance their writing skills and achieve better scores in writing tasks of participants in this suburban school.

There are several different ways to help develop pupils' writing skills but implementing proverbs via online tools; ProvWrit is one of the best choices. This is due to many pupils' inherent interest in all things technological. They have an enthrallment with any new tool that can make writing task fascinating. ProvWrit is used as a tool for formative assessment via a free game based online platform Kahoot. Pupils and teachers could see immediate feedback between questions. Pupils earned more points for quick answers and they could see how they rank between each question. Eventually, pupils hardly noticed they were evaluating their own knowledge and being evaluated. It 
was actually a collection of practices, which helped the pupils optimised learning and lead to their writing improvement. In a Malaysian ESL framework, the tool also helped educators to determine what they need to do to move the learners forward before the actual writing task.

The findings of online quizzes and forum discussion revealed the participants had a positive experience and enjoyed learning proverbs on Kahoot games. They had a better understanding of the proverbs and confidence to use them correctly in their writing. Moreover, participants accomplished better marks in short essay writing in a post-test stage. It showed a positive and significant influence on participants' writing skills. Most of them believed that their writing skills improved as a result of the project. Haryanti (2017) conducted a research considering if proverbs can enhance ESL learners' writing skills. The findings showed that writing a paragraph based on proverbs is believed to organize the thoughts and reveal the essence of one's ideas. They go in line with the findings of the present research. Therefore, using ProvWrit would be an effective tool to help pupils develop not only their writing skill comprehensively but also ability in organization and promote critical thinking. The findings recorded in both school proved that ProvWrit improves pupils' writing performance regardless of the locations; suburban secondary school in Pasir Gudang, Johor; the southern part of Peninsular Malaysia and the suburban secondary school in Sepang, Selangor; the west coast of peninsular Malaysia.

\section{CONCLUSIONS \& IMPLICATIONS}

The $21^{\text {st }}$ century is an opening of a new boundary in teaching and learning. Educators should promote critical thinking skills, creativity, collaboration and digital literacy to be embedded in the curriculum. By doing this, it would allow the production of original and creative ideas from the students and prepare them for the future. Hence, it is important to enhance writing skills because gaining good knowledge and improving writing skills effectively can lead the students to get professional success in the future. ProvWrit is a great way to start a writing class. It promotes a source of wisdom and knowledge. Students learned independently and collaboratively when doing online activities. There was very limited assistance from the teachers. A study by Yunus et. al (2014) found that the integration of ICT in the teaching of writing encourage learners' independence and self-discovery skills. This supports findings by Blachowicz et al. (2009) who found out that the learning technology allowed students to develop independent work habits and to build both their skills and confidence about literacy and about using technology. ProvWrit measure students writing and mastery of $21^{\text {st }}$ century skills through a balance of technology-enhanced in formative and summative assessments. It emphasized useful feedback on pupils' performance that is inserted into everyday learning. From the perceptions of 56 participants in this research, ProvWrit enhances their writing skills. Besides, collaborative learning during a PinUp forum discussion helped them to get better ideas for writing essays. The limitation that teachers need to pay attention to is the writing process was not emphasized during the session. Nevertheless, pupils have learned the process earlier. It is recommended that future research should focus more on the perceptions of teachers, interaction process during pupils' collaborative learning and limitations of learning proverbs in enhancing writing skills. Conclusively, it is hoped that the effectiveness of ProvWrit would enable reaching high levels of pupils' writing competency in $21^{\text {st }}$ century classroom. 
INTERNATIONAL JOURNAL OF ACADEMIC RESEARCH IN BUSINESS AND SOCIAL SCIENCES

Vol. 9, No. 1, Jan, 2019, E-ISSN: 2222-6990 (C) 2019 HRMARS

\section{Corresponding Author}

Melor Md. Yunus, Faculty of Education, Universiti Kebangsaan Malaysia, Bangi, Selangor

\section{References}

Aydin, Z., \& Yildiz, S. (2014). Using wikis to promote collaborative EFL writing. Language Learning \& Technology, 18(1), 160-180.

Baharian, E., \& Rezai, M. J. (2014). The effect of proverbs on learning vocabulary through visual organizers. International Journal of English Language Teaching, 2(4), 16-32.

Che Mat, S.S \& Yunus, M. M. (2014). Attitudes and Motivation Towards Learning English Among FELDA School Students. Australian Journal of Basic and Applied Sciences, 8(5), 1-8.

Firmansyah, A. (2015). The influence of mind mapping technique and students' attitude toward students' ability in writing a recount text of the eighth grade students of State Junior High School 45 Palembang. Ripteksi Kependidikan Pgri.

Haryanti, D. (2017). Draw Me A Proverbs: enhancing writing skills through wisdom. The $4^{\text {th }} U A D$ TEFL International Conference. Yogyakarta. ISBN 978-602-18907-2-1

Husnu M. \& Hamzanwadi. (2018). Demonstration technique to improve vocabulary and grammar element in teaching speaking at EFL learner. English Language Teaching; Volume (11), No. 2; 2018 ISSN 1916-4742 E-ISSN 1916-4750

Madut, I. T. \& Yunus, M. M. (2016). Popsicle Simile: an innovative tool in promoting creative writing among rural primary school ESL learners. International Coference on Education. Malang.

Majid, F. A., Zamin, A. A. M. \& Kamarudin, M. F. (2017). Toolkits for $21^{\text {st }}$ Century Teaching: Practical Implications for the $4^{\text {th }}$ Industry Skills Development. Shah Alam. Universiti Institut Teknologi Mara.

Malaysian National Education Blueprint (2013- 2025).http://.www.moe.gov.my

Mieder W. (2004). Proverbs : A Handbook. London. Greenwood Publishing Group.

Vanyushkina-Holt, N. (2005). Proverbial language and its role in acquiring a second language and culture. The Case of Russian. Diss. Bryn Mawr, Pennsylvania.

Vasiljević, Z. (2013). Effects of Learner-Generated Illustrations on Comprehension and Recall of L2 Idioms. ELTA Journals, 1 (1), 24-46. 
INTERNATIONAL JOURNAL OF ACADEMIC RESEARCH IN BUSINESS AND SOCIAL SCIENCES

Vol. 9, No. 1, Jan, 2019, E-ISSN: 2222-6990 ㄷ 2019 HRMARS

Yunus M. M \& Sallehi H. (2012). The Effectiveness of Facebook Groups on Teaching and Improving Writing: Students' Perceptions. International Journal of Education And Information Technologies, Volume 6(1).

Yunus M. M \& Suliman A. (2014). Information \& Communication Technology (ICT) Tools in Teaching and Learning Literature Component in Malaysian Secondary Schools. Asian Social Science, Volume 10 (7). ISSN 1911-2017 E-ISSN 1911-2025

Yunus M. M \& Chan, H. C (2016). The Use of Mind Mapping Strategy in Malaysian University English Test (MUET) Writing. Creative Education, Volume 7, 619-626. http://dx.doi.org/10.4236/ce.2016.74064 